\title{
Socio-demographic and intestinal elimination profile in women treated at a health service
}

\section{Perfil sociodemográfico e de eliminações intestinais em mulheres atendidas em um serviço de saúde}

\section{Perfil sociodemogrófico y de eliminación intestinal en mujeres tratadas en un senvicio de salud}

Rhaylla Maria Pio Leal Jaques, ,* Elaine Carininy Lopes da Costa², Gisela Maria Assis³, Aline Costa de Oliveira4, Claudia Daniella Avelino Vasconcelos Benício5, Sandra Marina Gonçalves Bezerra ${ }^{4}$

ORCID IDs

Jaques RMPL (D) https://orcid.org/ 0000-0002-2250-3886

Costa ECL (D) https://orcid.org/0000-0002-5387-978X

Assis GM (DD https://orcid.org/ 0000-0001-6343-8075

Oliveira AC (iD https://orcid.org/ 0000-0003-1738-4808

Benício CDAV (iD https://orcid.org/ 0000-0003-4638-2465

Bezerra SMG (D) https://orcid.org/ 0000-0003-3890-5887

\section{HOW TO CITE}

Jaques RMPL; Costa ECL; Assis GM; Oliveira AC; Benício CDAV; Bezerra SMG. Socio-demographic and intestinal elimination profile in women treated at a health service. ESTIMA, Braz. J. Enterostomal Ther., 18: e0820, 2020. https://doi.org/10.30886/estima.v18.830_IN

\begin{abstract}
Objective: To investigate the profile of intestinal eliminations in women. Method: Cross-sectional study conducted with 41 women seen at a women's health center in the state of Piauí in Brazil. For data collection, a form was used containing the sociodemographic data and questionnaires that assessed the data on the intestinal elimination pattern with questions based on the Rome IV criteria and the Bristol scale. Results: Of the 41 participants, 56.1\% reported consuming one to two servings of fruits or vegetables per day and $51.2 \%$ consumed more than two liters of water per day. Regarding the patterns of intestinal elimination, 39\% had feces in the Bristol 3 category. As for the Rome IV criteria, 21 (51.2\%) women were considered constipated and the frequency of evacuation was statistically significant with the presence of constipation. Conclusion: There was a significant number of women with constipation. There was a need to develop actions that help to cope with the problem and improve the quality of life of this population.
\end{abstract}

DESCRIPTORS: Constipation. Health profile. Women's health. Enterostomal therapy.

\begin{abstract}
RESUMO
Objetivo: Investigar o perfil de eliminações intestinais em mulheres. Método: Estudo transversal, realizado com 41 mulheres atendidas em um centro de saúde da mulher no estado do Piauí no Brasil. Para coleta de dados foi utilizado um formulário contendo os dados sociodemográficos e questionários que avaliaram os dados do padrão de eliminação intestinal com perguntas fundamentadas nos critérios de Roma IV e escala de Bristol. Resultados: Das 41 participantes, 56,1\% relataram consumir de uma a duas porções de frutas ou verduras por dia e 51,2\% consumiam mais de dois litros de água por dia. Com relação aos padrões de eliminação intestinal, 39\% apresentavam fezes na categoria Bristol 3. Quanto aos critérios de Roma IV, 21 (51,2\%) mulheres foram consideradas constipadas e a frequência de evacuação teve significância estatística com a presença de constipação. Conclusão: Houve um número expressivo de mulheres com constipação intestinal. Observou-se a necessidade de desenvolver ações que auxiliem no enfrentamento do problema e melhore a qualidade de vida dessa população.
\end{abstract}

DESCRITORES: Constipação intestinal. Perfil Epidemiológico. Saúde da mulher. Estomaterapia.

\footnotetext{
1.Clínica Integrada de Saúde da Mulher - Picos (PI), Brazil

2.Instituto Federal do Piauí - Setor de Saúde - Oeiras (PI), Brazil

3.Universidade Federal do Paraná - Ambulatório de Incontinência do Hospital das Clínicas - Curitiba (PR), Brazil

4. Universidade Estadual do Piauí - Coordenação de Enfermagem em Estomaterapia - Teresina (PI), Brazil

5. Universidade Federal do Piauí - Coordenação de Enfermagem - Teresina (PI), Brazil

*Correspondence author: rhaylla.maria@hotmail.com

Received: Nov. 28, 2019 | Accepted: Mar. 27, 2020
} 


\section{RESUMEN}

Objetivo: Investigar el perfil de eliminaciones intestinales en mujeres. Método: Estudio transversal realizado con 41 mujeres atendidas en un centro de salud para mujeres en el estado de Piauí en Brasil. Para la recolección de datos, se utilizó un formulario que contenía los datos sociodemográficos y los cuestionarios que evaluaban los datos sobre el patrón de eliminación intestinal con preguntas basadas en los criterios de Roma IV y la escala de Bristol. Resultados: De los 41 participantes, el 56.1\% informó consumir una o dos porciones de frutas o verduras por día y el 51.2\% consumió más de dos litros de agua por día. Con respecto a los patrones de eliminación intestinal, el 39\% tenía heces en la categoría de Bristol 3. En cuanto a los criterios de Roma IV, 21 (51,2\%) mujeres se consideraron estreñidas y la frecuencia de evacuación fue estadísticamente significativa con la presencia de estreñimiento. Conclusión: Hubo un número significativo de mujeres con estreñimiento y fue necesario desarrollar acciones que ayuden a enfrentar el problema y mejorar la calidad de vida de esta población.

DESCRIPTORES: Estreñimiento. Perfil de salud. Salud de la mujer. Estomaterapia..

\section{INTRODUCTION}

The pattern of intestinal elimination can influence the quality of life of an individual, especially when there are disorders in normal patterns of elimination. Among the disorders, the most important is the intestinal constipation (IC), which can influence people's daily lives ${ }^{1}$. Although these manifestations are not considered public health problems, they become relevant because they can trigger, in some cases, reactions that favor social isolation and low self-esteem, thus damaging the quality of life of the individual ${ }^{1}$.

Intestinal constipation is defined as unsatisfactory defecation, characterized by difficulty in passing stools, infrequent or hard stool, or sensation of incomplete evacuation, occurring in isolation or associated with an illness ${ }^{2}$. Although IC is not a threat to the individual's life, it has a negative effect on the quality of life ${ }^{3}$.

To complete the diagnosis of IC, the individual must show at least two or more of the following symptoms listed under the Rome IV criteria for at least three months: hard stools, frequency of bowel movements less than three times a week, effort when defecating, need to perform manual maneuvers, of incomplete bowel sensation movements at least $25 \%$ of the time, and/ or sensation of anorectal stool blocking/obstruction ${ }^{3,4}$.

Intestinal constipation is multifactorial and may be associated with systemic or neurological alterations, as well as with the use of inadequate drugs and diets with low fiber consumption, age, female gender, low socioeconomic level, low education level, endocrine and metabolic dysfunctions, physical inactivity, psychiatric disorders and idiopathic causes. In addition, IC can be an initial symptom of severe diseases such as colorectal cancer $^{5}$.

Regarding the management of IC, some strategies can be stimulated and guided by the nurse, especially the enterostomal therapist, such as a high-fiber diet, increased fluid intake, physical activity, use of a bench to improve posture at the time of evacuation, sitting in the toilet after meals preferably always at the same time to establish the routine (taking advantage of the increased gastrocolic reflex), performing the Valsalva maneuver (which consists of taking a deep breath and forcing the muscles of the abdomen and diaphragm down) as well as abdominal massages (massaging the colon from right to left, up and down, for twenty minutes) $)^{6,7}$.

The scarcity of official information considering the pattern of bowel and urinary elimination in women may hinder the planning and implementation of strategies and resource allocation for improved nursing care. In this sense, obtaining this information aims to provide better service to the client, expanding the role and professional commitment of the nurse from prevention to the rehabilitation process, applying the mediation of education in the search for autonomy to improve the quality of life of this clientele.

This study aimed to investigate the sociodemographic and intestinal elimination profile of women served in a reference center for women's health. 


\section{METHODS}

This is a transversal, descriptive research with a quantitative approach. The study was conducted at a Women's Health Center in the State of Piauí in Brazil. The study population consisted of women who were in the waiting room of the service for consultation. The sample was of a nonprobabilistic type, for convenience, and comprised 41 women attended in the service during the data collection period. Women over the age of 18 were included.

Data collection was conducted in June and July 2019 by the researcher responsible for the study. The women were approached individually in the waiting room, and informed about the survey by the researcher; those who agreed to participate were referred to a doctor's office, where the questionnaire was filled out with a guarantee of privacy.

The data collection instruments consisted of a form produced by the researcher for this research, containing the sociodemographic data and questionnaires that evaluated the data of the intestinal elimination pattern with questions based on the Rome IV criteria ${ }^{4}$ and Bristol scale ${ }^{8}$.

The Rome criteria is a recent guideline developed to standardize the diagnosis and management of constipation. If the participant presents, during a period of at least three months, two or more of the following criteria: hard stools, less than three spontaneous bowel movements per week, effort when defecating, manual maneuvers, sensation of incomplete evacuation, sensation of blocking/anorectal obstruction of stools, the diagnosis of $\mathrm{IC}^{4}$ is confirmed.

The Bristol scale is designed to evaluate and describe the form of fecal content, using graphic methods that represent seven types of feces, according to their shape and consistency, which is useful for patients to evaluate and describe aspects of their feces, facilitating recognition of the severity of constipation ${ }^{3}$. The types of feces described in the instrument are: type 1 (small hard balls, separated like coconuts - hard to get out), type 2 (sausage-shaped, but lumpy), type 3 (sausage-shaped with cracks on its surface), type 4 (sausage or snakeshaped, smooth and soft), type 5 (larger and separate pieces with well-defined edges - easy to remove), type
6 (pasty and fluffy mass with irregular edges), type 7 (totally liquid, without solid pieces) $)^{8}$.

The data were inserted in Microsoft Excel software and analyzed using the software Statistical Package for Social Science (SPSS) version 22.0, a tool for data processing and statistical analysis. Descriptive analyses were performed, such as measures of central tendency for numerical variables (mean and median), absolute and percentage frequency for qualitative variables and measures of dispersion or variability (standard deviation). Fisher's exact test was used for the inferential analysis, considering statistically significant results that had a value $p$ minor or equal to 0.05 .

All recommendations of Resolution 466/2012 of the National Health Council (NHC) were followed and the project was approved by the Research Ethics Committee of Universidade Estadual do Piauí with human beings under the opinion n. $3,447,450$.

\section{RESULTS}

Of the 41 participants of the research, 11 (26.8\%) were in the age group between 30 and 39 years, 13 (31.7\%) had completed elementary school and 24 (58.5\%) were married. As for the professional occupation, 13 (31.7\%) were farmers. Fifteen (36.6\%) of the participants had no associated disease. There was a predominance of 40 (97.6\%) nonsmoking women and 35 (85.4\%) did not consume alcoholic beverages, as shown in Table 1.

During the investigation of risk factors for intestinal constipation (IC), 24 (58.5\%) women reported that they urinated in bed at night and 19 (46.4\%) had no urine leakage during childhood, but 18 (43.9\%) did not remember having constipation during this period. About 21 (51.2\%) women surveyed reported good water intake, 23 (56.1\%) had low fiber intake, with vegetable consumption predominating from once to twice a day and 25 (61.1\%) had daily bowel movements. As for selfperception of anxiety, 32 (78\%) participants perceive themselves as anxious (Table 2).

When investigating the variables related to intestinal elimination, it was perceived that the most common type of stool, according to the Bristol scale, was type 3 , present in 16 (39\%) participants, followed by type 4 in $11(26.8 \%)$ people. 
Considering as IC the presence of two or more symptoms of the Rome IV criteria, 21 (51.2\%) women were constipated. Table 3 shows the frequency and percentage of each of the symptoms investigated by the Rome criteria.

Table 4 shows that the frequency of bowel movements had a statistical association with the intestinal constipation variable $(\mathrm{p}=0.007)$, in which it is possible to see that 11 (52.4\%) patients considered to have IC had a frequency of evacuation of only 2 to 4 times a week.

Table 1. Description of the sociodemographic characteristics of the study participants. Picos - Piauí - 2019.

\begin{tabular}{|c|c|c|c|}
\hline Characteristics & Category & $\mathrm{n}=41$ & $\%$ \\
\hline \multirow{5}{*}{ Age range } & From 18 to 29 years & 6 & 14.6 \\
\hline & From 30 to 39 years & 11 & 26.8 \\
\hline & From 40 to 49 years & 8 & 19.5 \\
\hline & From 50 to 59 years & 7 & 17.1 \\
\hline & Over 60 years & 9 & 22.0 \\
\hline \multirow{7}{*}{ Education level } & $\begin{array}{l}\text { Illiterate } \\
\text { I }\end{array}$ & 3 & 7.3 \\
\hline & Some elementary school & 4 & 9.8 \\
\hline & Elementary school & 13 & 31.7 \\
\hline & Some high school & 5 & 12.2 \\
\hline & High school & 8 & 19.5 \\
\hline & College & 7 & 17.1 \\
\hline & Some college & 1 & 2.4 \\
\hline \multirow{5}{*}{ Marital status } & Single & 4 & 9.8 \\
\hline & Married & 24 & 58.5 \\
\hline & Widower & 2 & 4.9 \\
\hline & Separate & 5 & 12.2 \\
\hline & Stable union & 6 & 14.6 \\
\hline \multirow{7}{*}{$\begin{array}{l}\text { Professional } \\
\text { occupation }\end{array}$} & Retired & 3 & 7.3 \\
\hline & Ploughwoman & 13 & 31.7 \\
\hline & Other & 12 & 29.3 \\
\hline & Student & 2 & 4.9 \\
\hline & Microentrepreneur & 1 & 2.4 \\
\hline & Teacher & 3 & 7.3 \\
\hline & Housewife & 7 & 17.1 \\
\hline \multirow{5}{*}{$\begin{array}{l}\text { Associated } \\
\text { disease }\end{array}$} & Hypertension & 11 & 26.8 \\
\hline & Anemia & 3 & 7.3 \\
\hline & Other & 7 & 17.1 \\
\hline & No & 15 & 36.6 \\
\hline & More than one option & 5 & 12.2 \\
\hline \multirow{2}{*}{ Smoke } & Yes & 1 & 2.4 \\
\hline & No & 40 & 97.6 \\
\hline \multirow{2}{*}{$\begin{array}{l}\text { Consumes } \\
\text { alcohol }\end{array}$} & Yes & 6 & 14.6 \\
\hline & $\mathrm{No}$ & 35 & 85.4 \\
\hline
\end{tabular}

Table 2. Description of the clinical characteristics of the study participants. Picos - Piauí - 2019.

\begin{tabular}{|c|c|c|c|}
\hline Characteristics & Category & $\mathrm{n}=41$ & $\%$ \\
\hline \multirow{3}{*}{$\begin{array}{l}\text { Urinated in bed } \\
\text { during sleep }\end{array}$} & Yes & 24 & 58.5 \\
\hline & No & 12 & 29.3 \\
\hline & Don't remember & 5 & 12.2 \\
\hline \multirow{3}{*}{$\begin{array}{l}\text { Urine leakage in } \\
\text { childhood }\end{array}$} & Yes & 6 & 14.6 \\
\hline & No & 19 & 46.4 \\
\hline & Don't remember & 16 & 39.0 \\
\hline \multirow{3}{*}{$\begin{array}{l}\text { Intestinal } \\
\text { constipation in } \\
\text { childhood }\end{array}$} & Yes & 6 & 14.6 \\
\hline & $\mathrm{No}$ & 17 & 41.5 \\
\hline & Don't remember & 18 & 43.9 \\
\hline \multirow{4}{*}{$\begin{array}{c}\text { How many } \\
\text { glasses of water } \\
\text { are consumed? }\end{array}$} & From 1 to 3 glasses/day & 4 & 9.8 \\
\hline & From 4 to 6 glasses/day & 11 & 26.8 \\
\hline & From 7 to 9 glasses/day & 5 & 12.2 \\
\hline & More than 10 glasses/day & 21 & 51.2 \\
\hline \multirow{3}{*}{$\begin{array}{l}\text { Consume fruits } \\
\text { and vegetables? }\end{array}$} & None & 6 & 14.6 \\
\hline & From 1 to 2 times/day & 23 & 56.1 \\
\hline & From 3 to 5 times/day & 12 & 29.3 \\
\hline \multirow{4}{*}{$\begin{array}{c}\text { Frequency of } \\
\text { evacuation }\end{array}$} & Every day & 25 & 61.1 \\
\hline & Once a week & 1 & 2.4 \\
\hline & From 2 to 4 times/week & 14 & 34.1 \\
\hline & Every 10 days & 1 & 2.4 \\
\hline \multirow{3}{*}{$\begin{array}{l}\text { Anxiety and/or } \\
\text { depression }\end{array}$} & Anxious & 32 & 78.0 \\
\hline & Not applicable & 7 & 17.1 \\
\hline & Both & 2 & 4.9 \\
\hline
\end{tabular}

Table 3. Description of the intestinal elimination characteristics of the study participants according to the Bristol scale and Rome IV criteria. Picos - Piauí - 2019.

\begin{tabular}{|c|c|c|c|}
\hline Characteristics & Category & $n=41$ & $\%$ \\
\hline \multirow{7}{*}{ Bristol scale* } & Bristol 1 & 7 & 17.1 \\
\hline & Bristol 2 & 5 & 12.2 \\
\hline & Bristol 3 & 16 & 39.0 \\
\hline & Bristol 4 & 11 & 26.8 \\
\hline & Bristol 5 & 5 & 12.2 \\
\hline & Bristol 6 & 2 & 4.9 \\
\hline & Bristol 7 & 1 & 2.4 \\
\hline \multicolumn{4}{|l|}{ Rome III criteria* } \\
\hline \multicolumn{2}{|c|}{ Effort to evacuate } & 17 & 41.5 \\
\hline \multicolumn{2}{|c|}{ Sensation of incomplete evacuation } & 16 & 39.0 \\
\hline \multicolumn{2}{|c|}{ Perform manual maneuvers } & 7 & 17.1 \\
\hline \multicolumn{2}{|c|}{ Lumpy or hard stools } & 20 & 48.8 \\
\hline \multicolumn{2}{|c|}{$\begin{array}{l}\text { Sensation of anorectal stool blocking/ } \\
\text { obstruction }\end{array}$} & 13 & 31.7 \\
\hline \multicolumn{2}{|c|}{ Evacuate less than three times a week } & 6 & 14.6 \\
\hline \multicolumn{2}{|c|}{ Constipation diagnosis } & 21 & 51.2 \\
\hline
\end{tabular}

*The participant could indicate more than one option, so the total frequency and percentage do not add up to 41 and 100\%, respectively. 
Table 4. Comparison between constipated and nonconstipated women and the clinical features regarding intestinal elimination. Picos - Piauí - 2019.

\begin{tabular}{|c|c|c|c|c|}
\hline \multirow{2}{*}{ Characteristics } & \multirow{2}{*}{ Category } & Constipated & Nonconstipated & \multirow{2}{*}{ p value } \\
\hline & & n (\%) & $\mathrm{n}(\%)$ & \\
\hline \multirow{3}{*}{$\begin{array}{l}\text { Intestinal constipation in } \\
\text { childhood }\end{array}$} & Yes & $4(19.0)$ & $2(10.0)$ & \multirow{3}{*}{$0.708 *$} \\
\hline & No & $9(42.9)$ & $8(40.0)$ & \\
\hline & Don't remember & $8(38.1)$ & $10(50.0)$ & \\
\hline \multirow{4}{*}{$\begin{array}{l}\text { How many glasses of } \\
\text { water are consumed? }\end{array}$} & From 1 to 3 glasses/day & $2(9.5)$ & $2(10.0)$ & \multirow{4}{*}{$0.860 *$} \\
\hline & From 4 to 6 glasses/day & $7(33.3)$ & $4(20.0)$ & \\
\hline & From 7 to 9 glasses/day & $2(9.5)$ & $3(15.0)$ & \\
\hline & More than 10 glasses/day & $10(47.6)$ & $11(55.0)$ & \\
\hline \multirow{3}{*}{$\begin{array}{c}\text { Consume fruits and } \\
\text { vegetables? }\end{array}$} & None & $3(14.3)$ & $3(15.0)$ & \multirow{3}{*}{$0.072^{*}$} \\
\hline & From 1 to 2 times/day & $15(71.4)$ & $8(40.0)$ & \\
\hline & From 3 to 5 times/day & $3(14.3)$ & $9(45.0)$ & \\
\hline \multirow{4}{*}{ Frequency of evacuation } & Every day & $8(38.1)$ & $17(85.0)$ & \multirow{4}{*}{$0.007 *$} \\
\hline & Once a week & $1(4.8)$ & $0(0.0)$ & \\
\hline & From 2 to 4 times/week & $11(52.4)$ & $3(15.0)$ & \\
\hline & Every 10 days & $1(4.8)$ & $0(0.0)$ & \\
\hline \multirow{3}{*}{$\begin{array}{l}\text { Anxiety and/or } \\
\text { depression }\end{array}$} & Anxious & $17(81.0)$ & $15(75.0)$ & \multirow{3}{*}{$0.836 *$} \\
\hline & Not applicable & $3(14.3)$ & $4(20.0)$ & \\
\hline & Both & $1(4.8)$ & $1(5.0)$ & \\
\hline
\end{tabular}

*Fisher's exact test

\section{DISCUSSION}

This study had the participation of women in the age group of 18 to 78 years, the most prevalent group being from 30 to 39 years, although the literature points out the prevalence of IC in women in the age group of 40 and 59 years $^{8}$.

Regarding the investigation of the participants' education level, it was possible to perceive low level of education with a predominance of married as marital status ${ }^{9,10}$. The literature also points to a higher prevalence of IC in females due to changes in the pelvic floor at gestation and childbirth ${ }^{5}$. In addition, hormonal issues are also pointed out as a risk factor for IC, such as the action of progesterone which is elevated in the luteal phase of the menstrual cycle and during the second and third trimesters of pregnancy, as well as damage to pelvic floor muscles during gynecological and obstetric surgeries which can increase the incidence ${ }^{11}$.

Regarding the occurrence of associated diseases, $26.8 \%$ of participants reported hypertension. This result confirms those found in a survey conducted in Northeastern Brazil on IC in which a similar prevalence of people with hypertension as comorbidity is reported among those investigated ${ }^{12}$. When investigating smoking among the participants, it was observed that the majority reported not being smokers. Although questionable, the literature points out that smoking is inversely proportional to IC; this occurrence is associated with the fact that nicotine is able to facilitate emptying the large intestine by relaxing the anal sphincter, which will influence bowel movement ${ }^{13}$.

As for the risk factors for the occurrence of IC, it was observed that most of the women investigated $(21 / 51.2 \%)$ consumed more than 10 glasses $(200 \mathrm{ml})$ of water per day. It is important to note that liquid intake, including juices and water, should be at least eight glasses/ day because proper hydration changes the consistency and weight of feces, increases the number of gastrocolic reflexes and contributes to intestinal lubrication ${ }^{14}$.

Regarding the consumption of fruits and vegetables, it was evidenced in this study that the majority consumed from one to two portions of fruits and vegetables per day, coinciding with a study carried out in Portugal that approached 202 people and evidenced that more $50 \%$ of the population consumed fruits and vegetables daily ${ }^{4}$. In contrast, a study showed that most participants did not 
always consume fruits and vegetables ${ }^{1}$. The dietary fibers present in fruits and vegetables are undigested components by digestive enzymes of the gastrointestinal tract of humans, dividing into soluble that collaborate to the softness of feces and insoluble that increase fecal volume, stimulating the peristaltic waves and the emptying of the colon ${ }^{15}$.

As for the frequency of evacuation, most participants reported that they evacuate every day. Different results were found in studies where there was a predominance of participants who evacuated only once a week ${ }^{11}$. This result reinforces the need to expand the concept of constipation, since, considering only the frequency of evacuation, the minority would appear to have constipation, but with the application of the Rome criteria, the symptoms pointed to other aspects of unsatisfactory evacuation.

With regard to emotional behavior, most of the participants reported suffering from anxiety. It is important to consider the association between IC and psychological conditions such as stress, anxiety and depression, because these manifestations predispose to IC, with possible implication in the etiology of the disease ${ }^{11}$.

When investigating the type of feces according to the Bristol scale, a higher frequency of stool type 3 was noticed, corroborating the results of several studies ${ }^{4,16,17}$. Regarding the ideal stool consistency, the literature points out that the stool classified as type 4, characterized as elongated stool, in sausage or snake format, smooth and soft, is the most adequate ${ }^{8}$.

In order to be diagnosed with an intestinal constipation, the individual must show at least two or more manifestations of the Rome IV criteria within a period of three months. In this study, it was observed that most participants had intestinal constipation ${ }^{4,17}$, with a predominance of lumpy or hard stools and a sensation of incomplete evacuation. Such result can also be found in several studies on the prevalence of intestinal constipation ${ }^{18,19}$.

It is worth mentioning that the sample size was a limitation of the study, imposed by the time available for data collection. This limitation may be the reason for the absence of an association between the diagnosis of intestinal constipation and widely known risk factors. Nevertheless, it draws attention to the number of women with constipation who describe themselves as anxious.

\section{CONCLUSION}

The study showed a significant presence of intestinal constipation among women attended at a women's health care center, even if this was not the reason for seeking the service. Although the relationship between variables has not been statistically proven, the number of women who recall having experienced enuresis in childhood and who consider themselves anxious is relevant.

The result points to a need to work on the issue among groups of women, knowing that it is a group more susceptible to the problem. It also awakens to the possibility of the nurse's action with health education actions, both in the sense of bringing the subject to discussion, and in direct action for prevention and treatment, whether in individual consultations, group actions or orientation campaigns.

It is suggested that other research involving the issue of intestinal constipation in women be carried out, enabling knowledge of the real dimension of the problem, as well as the evaluation of the results of prevention and treatment actions, in order to promote the insertion of the issue in primary and secondary health care, involving the nurse as an agent of change and promoter of quality of life, in this area still so neglected.

\section{ACKNOWLEDGMENTS}

To the women participants of this research and to the Coordination of Nurses of Professors and Nurses the First Specialization Class in Enterostomal Therapy from Universidade Estadual do Piauí, Brazil.

\section{AUTHOR'S CONTRIBUTION}

Conceptualization, Jaques RMPL, Assis GM and Oliveira AC; Investigation, Jaques RMPL; Writing Original Draft, Jaques RMPL, Costa ECL, Assis GM, Oliveira AC, Benício CDAV and Bezerra SMG; Writing - Review and Editing, Jaques RMPL, Costa ECL, Assis GM, Oliveira AC, Benício CDAV and Bezerra SMG; Supervision, Jaques RMPL. 


\section{REFERENCES}

1. Bomfim IQ, Nunes LS, Alves TC. Prevalência de constipação intestinal em estudantes de fisioterapia de uma Universidade de Maceió/AL. Rev Ciênc Méd Biol. 2017;16(1):79-84. https:// doi.org/10.9771/cmbio.v16i1.13266

2. Schmidt FMQ, Santos VLCG, Domansky RC, Barros E, Bandeira MA, Tenório MAM, et al. Prevalência de constipação intestinal autorreferida em adultos da população geral. Rev Esc Enferm USP. 2015;49(3):443-52. https://doi. org/10.1590/S0080-623420150000300012

3. Sobrado CW, Corrêa Neto IJF, Pinto RA, Sobrado LF, Nahas SC, Cecconello I. Diagnosis and treatment of constipation: a clinical update based on the Rome IV criteria. J Coloproctol. 2018;38(2):137-44. https://doi.org/10.1016/j. jcol.2018.02.003

4. Azevedo R, Ribeiro H, Pinto J, Leitão C, Caldeira A, Banhudo A. Modelo preditivo de obstipação: o que poderá ser útil para além do Roma IV? Rev Port Coloproct. 2017;14(2):12-9.

5. Garcia LB, Bertolini SMMG, Souza MV, Santos MSF, Pereira COM. Constipação intestinal: aspectos epidemiológicos e clínicos. Saúde Pesqui. 2016;9(1):153-62. https://doi. org/10.17765/1983-1870.2016v9n1p153-162

6. Machado D, Assis GM. Padrão intestinal e medidas de controle adotadas por pacientes com trauma raquimedular. ESTIMA, BrazJ Enterostomal Ther. 2018;16:e1418.

7. Braz MM, Kelling BI, Arruda GT, Stallbaum JH. A constipação intestinal em idosas participantes de um programa de promoção à saúde, em Santa Maria (RS): sua prevalência, sintomas e fatores psicossociais associados. Rev Kairós. 2015;18(3):381-95.

8. Martinez AP, Azevedo GR. Tradução, adaptação cultural e validação da Bristol Stool Form Scale para a população brasileira. Rev Latino-Am Enfermagem. 2012;20(3):1-7. https://doi.org/10.1590/S0104-11692012000300021

9. Cunha RM, Leite LC, Oliveira GND, Brito GA, Figueredo VB, Nascimento SL. Perfil epidemiológico e sintomas urinários de mulheres com disfunções do assoalho pélvico atendidas em ambulatório. Rev Fisioter S Fun. 2016;5(1):42-9.

10. Lopes MHBM, Costa JN, Bicalho MB, Casale TE, Camisão AR, Fernandes MLV. Profile and quality of life of women in pelvic floor rehabilitation. Rev Bras Enferm. 2018;71(5):2642-51. https://doi.org/10.1590/0034-7167-2017-0602

11. Trisógilio C, Marchi CMG, Torres US, Netinho JG. Prevalência de constipação intestinal entre estudantes de medicina de uma instituição no Noroeste Paulista. Rev Bras Coloproct. 2010;30(2):203-9. https://doi.org/10.1590/S010198802010000200012

12. Silva MS, Pinho CPS. Constipação intestinal: prevalência e fatores associados em pacientes atendidos ambulatorialmente em hospital do Nordeste brasileiro. Nutr Clín Diet Hosp. 2016;36(1):75-84. https://doi. org/10.12873/361sousa

13. Jaime RP, Campos RC, Santos TST, Marques MS. Prevalência e fatores de risco da constipação intestinal em universitários de uma instituição particular de Goiânia, GO. Rev Inst Ciênc Saúde. 2009;27(4):378-83.

14. Gavanski DS, Baratto I, Gatti RR. Avaliação do hábito intestinal e ingestão de fibras alimentares em uma população de idosos. Rev Bras Obes Nutr Emagrecimento. 2015;9(49):3-11.

15. Muñoz RLS, Santos LA, Martins MMC, Araújo DU, Vieira ATP, Vilar GN, et al. Constipação intestinal e fatores associados em estudantes universitários da área de saúde. Rev Salusvita (Online). 2016;35(3):351-66.

16. Dall Agnol TM, Araújo MP, Laino F, Parmigiano TR, Girão MJBC, Sartori MGF. Avaliação do habito intestinal em mulheres atletas e sua relação com nível de hidratação e uso de suplemento. Rev Bras Nutr Esportiva. 2016;10(58):458-66.

17. Pinheiro AK, Geron VLMG, Terra Júnior AT, Nunes JS, Brondani FMM. Constipação intestinal: tratamento com fitoterápicos. Rev Cient Fac Educ e Meio Ambient. 2018;9(ed esp):559-64. https://doi.org/10.31072/rcf.v9iedesp.598

18. Olivon EV, Costa JJ, Machado AD, Chaud DMA, Abreu ES. Prevalência e fatores associados à constipação intestinal funcional em universitários. Ciência e Saúde. 2016;9(3):1505. https://doi.org/10.15448/1983-652X.2016.3.22591

19. Sant'Anna MSL, Ferreira CLLF. Prevalência de constipação intestinal no município de Viçosa/MG. Nutrição Brasil. 2016;15(1):10-4. 